\title{
Non-invasive ploidy determination in live fish by measuring erythrocyte size in capillaries
}

\author{
Karel HALAČKA ${ }^{1,2}$, Karel JANKO², Lukáš VETEŠNÍK ${ }^{1}$ \\ 1 Institute of Vertebrate Biology of the Czech Academy of Sciences, Brno, Czech Republic \\ 2 Institute of Animal Physiology and Genetics of the Czech Academy of Sciences, Libèchov, Czech Republic \\ http://zoobank.org/BC3B1EC6-819B-4252-AE52-1A75FEAB8058 \\ Corresponding author: Karel Halačka (halacka@ivb.cz)
}

Academic editor: Jolanta Kiełpińska • Received 4 October 2020 • Accepted 4 March 2021 • Published 9 September 2021

Citation: Halačka K, Janko K, Vetešník L (2021) Non-invasive ploidy determination in live fish by measuring erythrocyte size in capillaries. Acta Ichthyologica et Piscatoria 51(3): 275-280. https://doi.org/10.3897/aiep.51.65718

\begin{abstract}
Information about ploidy is important in both commercial and conservation aquaculture and fish research. Unfortunately, methods for its determination, such as karyology, determination of the amount of DNA in a cell using microdensitometry or flow cytometry and/or measuring erythrocytes in a blood smear can be stressful or even destructive. Some of these methods are also limited by the relatively large minimum size of the individual being measured. The aim of this study was to test a new low-stress method of determining ploidy by measuring the size of erythrocytes in the capillaries of a fish, including small individuals. First, we examined diploid and triploid loach (Cobitis sp.) and gibel carp, Carassius gibelio (Bloch, 1782), using flow cytometry and blood smears, with these results being used as a control. Subsequently, we measured the size of erythrocytes in the caudal fin capillaries of anesthetized fishes of known ploidy under a light microscope. For both the loaches and gibel carp, direct observation of the mean erythrocyte size in epithelial fin capillaries provided a consistent and reliable determination of ploidy when compared with the controls based on flow cytometry and blood smears. This new method allows for rapid determination of ploidy in living small fish, where collection of tissue using other methods may cause excessive stress or damage. The method outlined here simply requires the measurement of erythrocytes directly in the bloodstream of a live fish, thereby making it possible to determine ploidy without the need for blood sampling. The method described is sufficiently efficient, less demanding on equipment than many other procedures, can be used by relatively inexperienced personnel and has benefits as regards animal welfare, which is especially important for fish production facilities or when dealing with rare or endangered species.
\end{abstract}

\section{Keywords}

Carassius, Cobitis, erythrocyte, non-invasive measurement, ploidy determination

\section{Introduction}

Polyploidy, the multiplication of whole sets of chromosomes beyond the normal set of two, occurs independently in many groups of fish, from sharks to the higher teleosts. While there are several ways that a polyploid fish can develop, environmental change and hybrid stabilization may play a large role in the initiation of a new polyploid species. Polyploid fish could gain an advantage over diploid fish through increased heterozygosity, the divergence of duplicate genes, and/or increased expression of key physiological proteins (Leggatt and Iwama 2003). Hybridization and polyploidization thus became increasingly appreciated as important evolutionary mechanisms that even had a profound impact on mankind, such as increased crop yields, quality or pathogen-resistance (Mason and Batley 2015).

At the phenotypic level, the effects of polyploidization are often mild and idiosyncratic (Otto 2007). Cell volume generally rises with increasing genome size

Copyright Halačka et al. This is an open access article distributed under the terms of the Creative Commons Attribution License (CC BY 4.0), which permits unrestricted use, distribution, 
(Cavalier-Smith 1978; Gregory 2001), although the exact relation between ploidy and cell volume varies among environments and taxa.

Further, although cell size typically is larger in polyploids, adult size may or may not be altered; as a rough generalization, polyploidization is more likely to increase adult body size in plants and invertebrates than in vertebrates (Otto and Whitton 2000; Gregory and Mable 2005).

Triploidy may be accompanied by morpho-anatomical changes to the organs. Changes may occur not only in proportion but also as anomalies or deformations that have clearly negative impacts on the individual. For example, in fish, negative changes may include gill defects such as missing gill filaments, leading to a reduction in gill surface area, as recorded in triploid Salmo salar by Sadler et al. (2001).

In addition to possible changes in organ structure, polyploid individuals may also show differences in physiology. Previous studies have tended to focus on differences in metabolism rates between diploid and triploid fish or the ability to survive in oxygen-poor environments. The results of these studies have tended to be ambiguous, however, showing variability within both species and developmental stages, depending on test conditions (e.g., Benfey and Sutterlin 1984; Lilyestrom et al. 1999; Ellis et al. 2013).

Polyploidy is especially common in loach (Cobitis sp.) (Papoušek et al. 2008), gibel carp, Carassius gibelio (see Vetešník et al. 2006) complexes and in artificial fish farming conditions (Piferrer et al. 2009; Preston et al. 2013; Fiske et al. 2019). These hybrid diploid polyploid complexes and polyploidization are currently intensively used in a whole range of studies, from evolutionary issues to fish production (Kotusz et al. 2014; Pakosta et al. 2018; Bartoš et al. 2019).

To accurately identify individual biotypes, it is necessary to gradually combine several diagnostic approaches: sequencing of mitochondrial and nuclear markers, allozyme analysis, and cytogenetic tools (e.g., karyotyping and C-banding), including the determination of degrees of ploidy (Bohlen and Ráb 2001).

Three basic methods were used in the presently reported study to detect polyploidy: i) karyology (e.g., Blaxhall 1975), the only method able to determine the exact number of chromosomes; ii) determination of the amount of DNA in a cell using microdensitometry (e.g., Gervai et al. 1980; Hardie et al. 2002) or flow cytometry (e.g., Thorgaard et al. 1982); or iii) comparison of whole erythrocyte or nucleus size between ploidies, using, for example, a microscope or an automated particle size analyzer (e.g., Thorgaard and Gall 1979; Benfey et al. 1984; Flajšhans 1997; Fiske et al. 2019). These methods usually have a number of limitations, including the necessity for specialized equipment, a need to kill (especially in karyology or flow cytometry of muscle tissue), or otherwise damage the fish (e.g., through fin clipping or removal of blood for flow cytometry or blood smears) and/or financial and time constraints
In this paper, we present a new method for determining ploidy based on the measurement of erythrocyte size in caudal fin capillaries. The method is non-invasive, suitable for small fish that should not be killed, affordable, and does not require specialized equipment.

\section{Methods}

For this study, we examined 20 loaches $(10 \times$ diploid Cobitis elongatoides, $10 \times$ triploid C. elongatoides $\times$ C. tanaitica; standard length [SL] $6.0-8.5 \mathrm{~cm}$ and 20 gibel carp (10× diploid, $10 \times$ triploid; SL 1.5-2.5 cm). Ploidy in these individuals was initially determined by flow cytometry (as DNA content using a Partec CCA flow cytometer; dyed with DAPI-CyStain DNA 1-step solution) on a blood sample (loach $2 \mathrm{n}=103.6 \%(96.0-112.0)$; $3 \mathrm{n}=153.8 \%(142.0-164.4) ;$ gibel carp $2 \mathrm{n}=97.8 \%$ (94.4-104.4); 3n $=(154.0 \%(146.6-162.8))$ (Flajšhans et al. 2005), using the gold fish (Carassius auratus) as a standard $(=100 \%)$, and a separate blood smear (Boroń 1994) for measurement of length erythrocyte (without staining). These data were used as a control for comparison with the new method.

The fish used for measurement of erythrocyte size in caudal fin capillaries were immobilized on the mechanical stage of an Olympus BX50 light microscope using a $36 \times 125 \mathrm{~mm}$ 'pad' with two overlapping tiles glued to the underlying glass (Fig. 1). This allowed for the placement of individuals exceeding the length of the classical glass (76 $\mathrm{mm}$ ) as well as allowing the pad to be fastened using stage clips and moved with the stage controls.

The individual being examined was first anesthetized with clove oil $(0.05 \mathrm{~mL}$ in $1 \mathrm{~L}$ of water; Svoboda and Kolářová 1999) and then placed on its side on the underlying glass. The caudal fin was then stretched, allowing blood in the epithelial capillaries to be observed using a $40 \times$ lens. At the same time, an image was transferred to the computer screen using an Olympus DP70 camera. In vivo measurements (major axes) were obtained for 20 cells using Photoshop software. As the high velocity of the blood cells usually did not allow for high quality photographic capture, images were obtained from localities where blood flow was reduced to a minimum.

\section{Results}

For both the loaches and gibel carp, direct observation of mean erythrocyte size in epithelial fin capillaries provided a consistent and reliable determination of ploidy (Table 1; Figs 2-4), using flow cytometry and blood smears as controls.

The ratio of the mean fin capillary erythrocyte length was similar to that for blood smears, the lower absolute values observed using blood smears most likely being the result of cell shrinkage after drying on the surface of the glass or that larger values obtained using this new method 

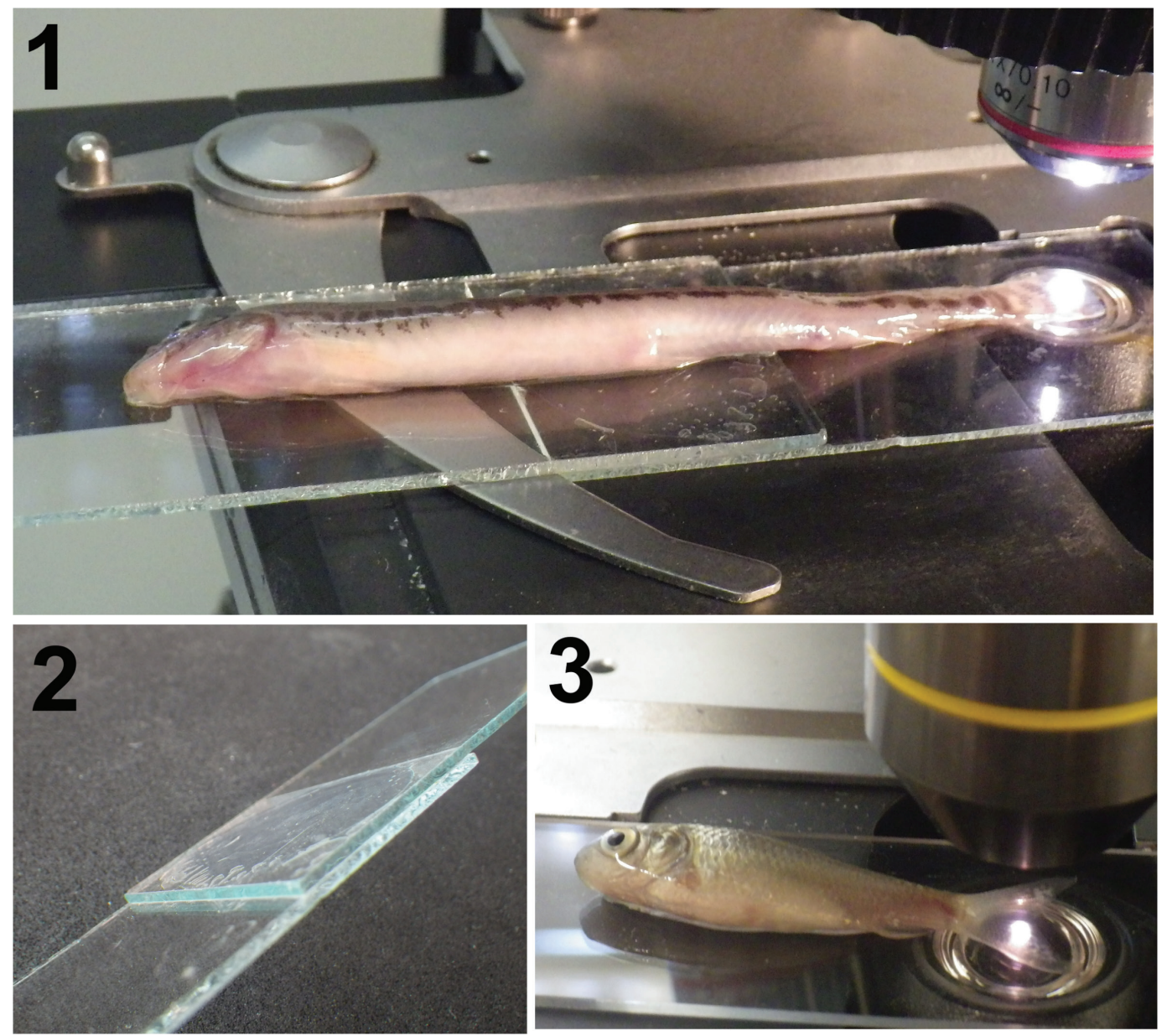

Figure 1. Loach (1) and gibel carp (3) mounted on the light microscope using the pad made from two overlapping underlying glass (2).

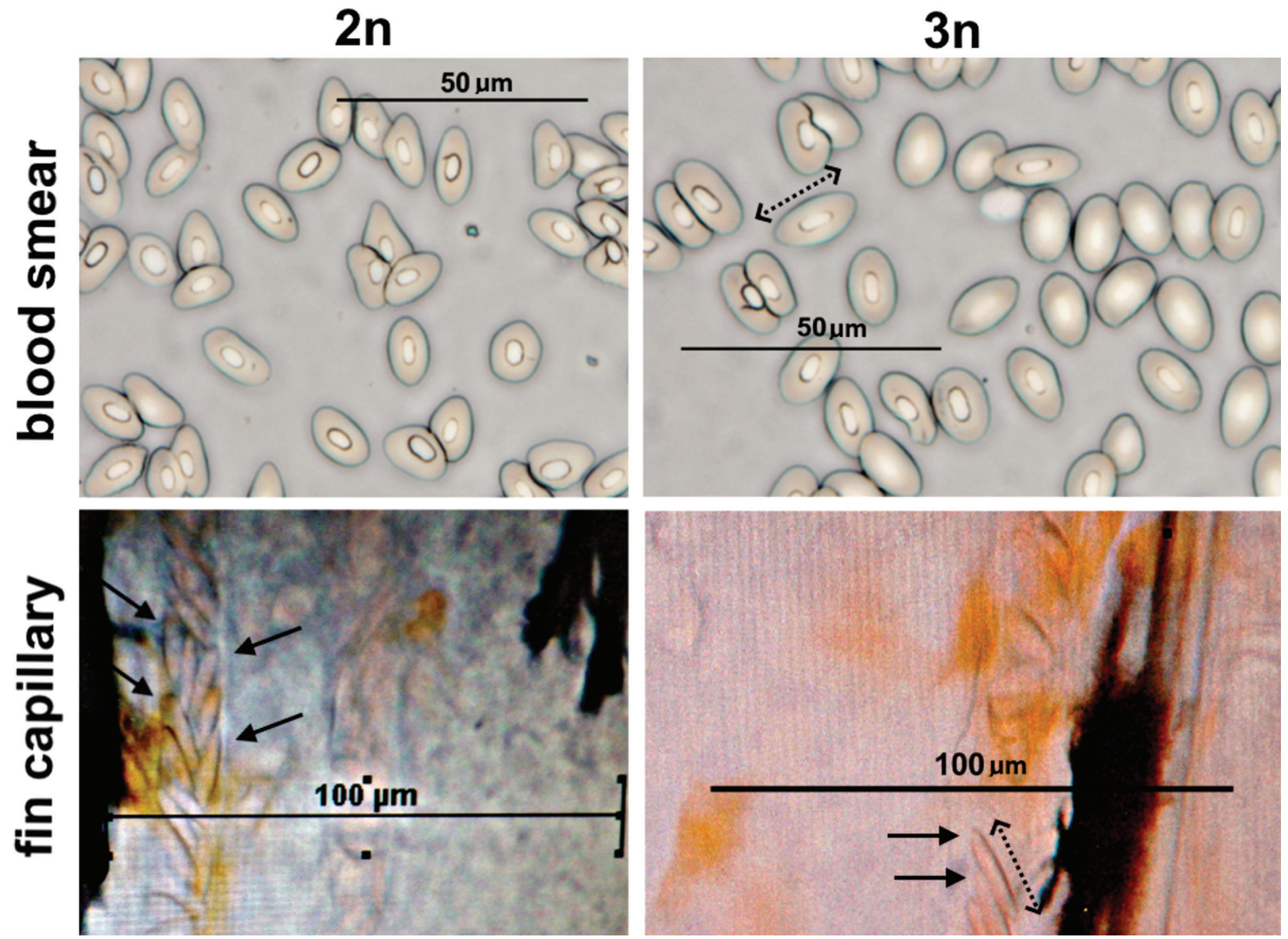

Figure 2. Erythrocytes of gibel carp; arrows = erythrocytes in capillaries, dotted line = erythrocyte length. 


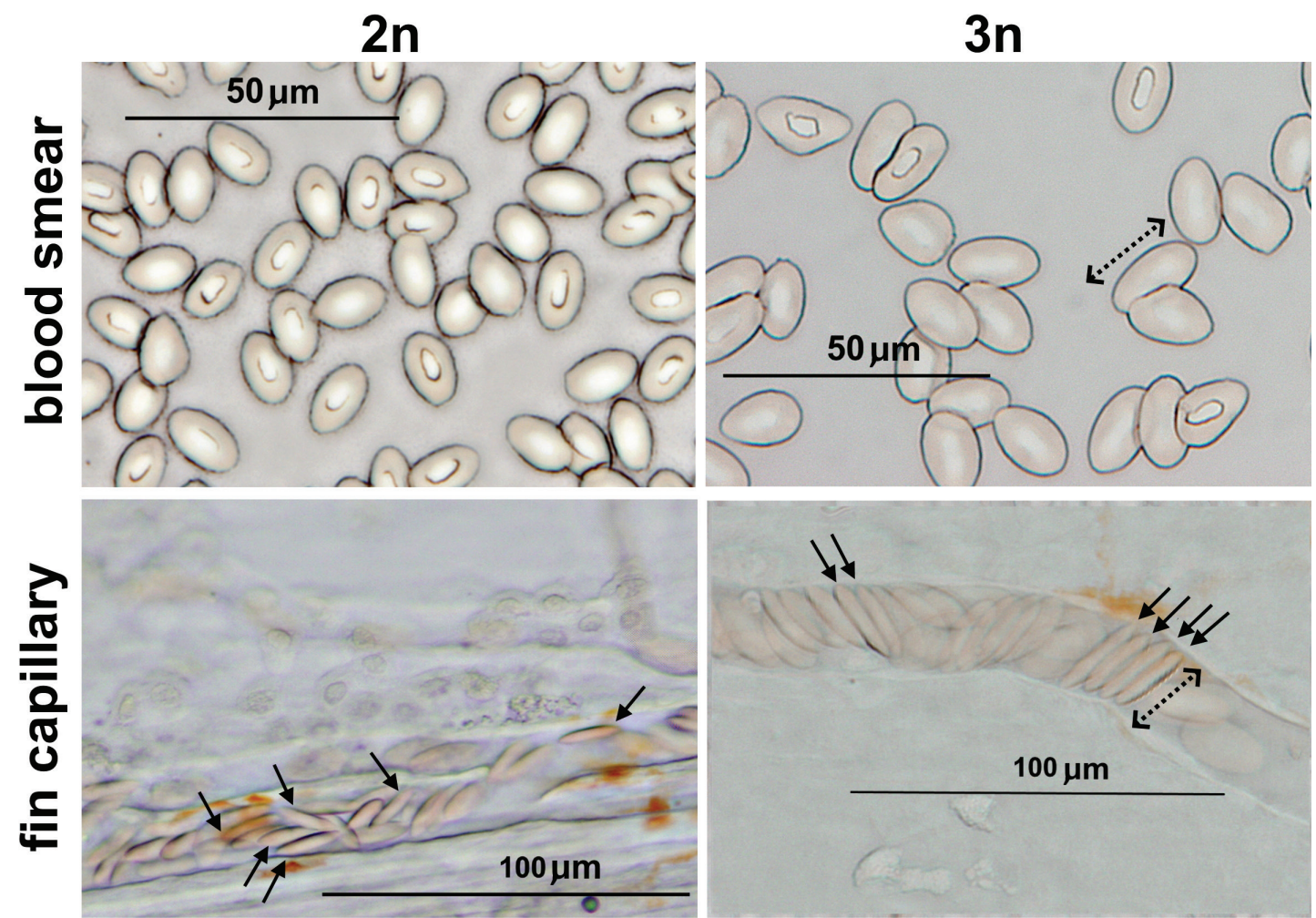

Figure 3. Erythrocytes of cobitids; arrows = erythrocytes in capillaries, dotted line = erythrocyte length.

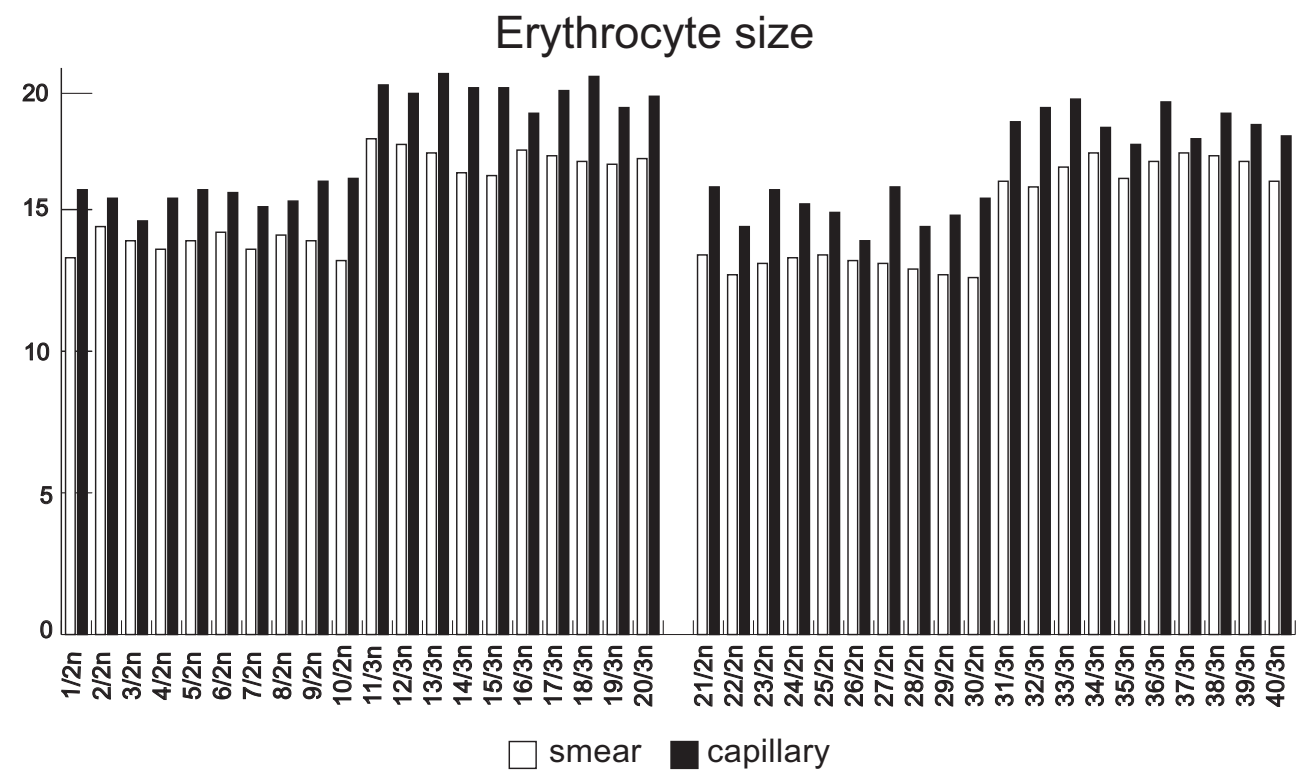

Figure 4. Erythrocyte length (mean in $\mu \mathrm{m})$ for loach $(1-10=$ diploid/2n; $11-20=$ triploid/3n) and gibel carp $(21-30=$ diploid; $31-40=$ triploid $)$, measured from blood smears and directly from fin capillaries.

Table 1. Erythrocyte length $[\mu \mathrm{m}]$ for loach (Cobitis sp.) and gibel carp (Carassius gibelio) measured from blood smears and direct from fin capillaries.

\begin{tabular}{lcccccccc}
\hline Species & Source & \multicolumn{3}{c}{ 2n } & \multicolumn{3}{c}{ 3n } & \multicolumn{2}{c}{$\begin{array}{c}\text { 2n:3n } \\
\text { ratio }\end{array}$} \\
\cline { 3 - 8 } & & Mean & Range & SD & Mean & Range & SD & \\
\hline \multirow{2}{*}{ Loach } & Smear & 13.8 & $13.1-14.4$ & 0.35 & 16.9 & $16.2-17.5$ & 0.42 & $1: 1.22$ \\
& Capillary & 15.5 & $14.6-16.1$ & 0.39 & 19.3 & $18.4-19.8$ & 0.43 & $1: 1.25$ \\
\multirow{2}{*}{ Gibel } & Smear & 13.2 & $12.7-13.4$ & 0.24 & 16.3 & $15.5-17.0$ & 0.43 & $1: 1.25$ \\
carp & Capillary & 15.0 & $13.9-15.8$ & 0.68 & 17.9 & $16.4-18.9$ & 0.54 & $1: 1.19$ \\
\hline \multirow{2}{*}{ SD = standard deviation } & & & & & & &
\end{tabular}

were due to cell deformation (stretching) of the cells by passage through a capillary.

\section{Discussion}

A range of methods have been used to identify polyploid fish; however, each has specific limitations. While chromosome preparation and counting are now considered inexpensive and require little specialized 
equipment, it is not always easy to perform or successful. Further, while there are exceptions (see Kalous et al. 2010), the method requires that the fish be killed and the results take time, often up to $24 \mathrm{~h}$ (e.g., Kligermann and Bloom 1977; Felip et al. 2009). A second method frequently utilized is the measurement of DNA content in individual blood cells (Wolters et al. 1982; Kotusz 2008), muscle samples, or from a fin clip using either microfluorimetry, microdensitometry (Gervai et al. 1980), or flow cytometry (Thorgaard et al. 1982). In the case of blood samples and fin clips, while there is no need to kill the fish and the results are obtained relatively quickly (minutes to tens of minutes), the method is expensive and requires specialized equipment. Finally, ploidy has also been determined by measuring the length and width of whole red blood cells or (more often) their nuclei. By using a suitable nuclear staining technique (e.g., Giemsa, hematoxylin), the nucleus "area" can also be determined through image analysis (Cherfas 1966; Benfey et al. 1984; Felip et al. 2009). Though the results obtained from nucleus measurements tend to be statistically more significant, differences in the maximum whole-cell size tend to be sufficient to distinguish diploid and triploid individuals. While this method is relatively quick and inexpensive and does not require specialized equipment (aside from image analysis software) or chemicals, it does require a blood sample. Even in larger individuals (up to ca. $10 \mathrm{~cm}$ ), removal of a blood sample can result in injury or even the death of the fish; and in small individuals (up to $1-2 \mathrm{~cm}$ ), removal of a suitable blood sample may prove difficult.

\section{References}

Bartoš O, Röslein J, Kotusz J, Paces J, Pekárik L, Petrtýl M, Halačka K, Štefková Kašparová E, Mendel J, Boroń A, Juchno D, Leska A, Jablonska O, Beneš V, Šídová M, Janko K (2019) The legacy of sexual ancestors in phenotypic variability, gene expression, and homoeolog regulation of asexual hybrids and polyploids. Molecular Biology and Evolution 36(9): 1902-1920. https://doi.org/10.1093/molbev/msz114

Benfey TJ, Sutterlin AM (1984) Oxygen utilization by triploid landlocked Atlantic salmon (Salmo salar L.). Aquaculture 42(1): 69-73. https://doi.org/10.1016/0044-8486(84)90314-4

Benfey TJ, Sutterlin AM, Thompson RJ (1984) Use of erythrocyte measurements to identify triploid salmonids. Canadian Journal of Fisheries and Aquatic Sciences 41(6): 980-984. https://doi.org/10.1139/ f84-112

Blaxhall PC (1975) Fish chromosome techniques-A review of selected literature. Journal of Fish Biology 7(3): 315-320. https://doi. org/10.1111/j.1095-8649.1975.tb04605.x

Bohlen J, Ráb P (2001) Species and hybrid richness in spined loaches of the genus Cobitis (Teleostei: Cobitidae), 630 with a checklist of European forms and suggestions for conservation. Journal of Fish Biology 59(sa): 75-89. https://doi.org/10.1111/j.1095-8649.2001.tb01380.x

Boroń A (1994) Use of erythrocyte measurements to detect natural triploids of spined loach Cobitis taenia (L.). Cytobios 78: 197-202.
In comparison, the method outlined here simply requires direct measurement of erythrocytes in the bloodstream of a live fish, thereby making it possible to determine ploidy without the need for a blood sample of any kind. Our results indicate that the difference in erythrocyte size between diploid and triploid individuals is perfectly sufficient to reliably determine ploidy. Equipment requirements are limited to a standard optical microscope with a $40 \times$ zoom lens and a camera/video attachment allowing an image of the blood cells to be captured and measured. The fish can then be returned to the water after recovering from the anesthetic. Further, the level of stress is relatively low, especially compared to some of the "invasive" methods mentioned above.

\section{Conclusions}

The method described is sufficiently efficient, less demanding on equipment than many other procedures (e.g., flow cytometry, microdensitometry), for especially small fish, can be used by relatively inexperienced personnel and has benefits as regards animal welfare, which is especially important for fish production facilities or when dealing with rare or endangered species.

\section{Acknowledgments}

The research was supported by the Czech Science Foundation, Project No. GAČR 17-09807S and 19-21552S. Thanks go to Dr. Kevin Roche for language correction.

Cavalier-Smith T (1978) Nuclear volume control by nucleoskeletal DNA, selection for cell volume and cell growth rate, and the solution of the DNA C-value paradox. Journal of Cell Science 34(1): 247-278. https://doi.org/10.1242/jcs.34.1.247

Cherfas NB (1966) Natural triploidy in females of the unisexual form of the goldfish (Carassius auratus gibelio Bloch). Genetika 5: 16-24.

Ellis LE, Sacobie CF, Kieffer JD, Benfey TJ (2013) The effects of dissolved oxygen and triploidy on critical thermal maximum in brook charr (Salvelinus fontinalis). Comparative Biochemistry and Physiology 166(3): 426-433. https://doi.org/10.1016/j.cbpa.2013.07.026

Felip A, Carrillo M, Herráez MP, Zanuy S, Basurco B (2009) Protocol I-Preparation of metaphasic chromosomes [Practical guide of protocols: methods of verification of the ploidy]. Pp. 61-65. In: Felip A, Carrillo M, Herráez MP, Zanuy S, Basurco B (Eds) Advances in fish reproduction and their application to broodstock management: a practical manual for sea bass. Zaragoza: CIHEAM / CSIC-IATS: Options Méditerranéennes: Série B. Etudes et Recherches No. 63, 95 pp. Fiske JA, Van Eenennaam JP, Todgham AE, Youngb SP, Holem-Bell CE, Goodbla AM, Schreier AD (2019) A comparison of methods for determining ploidy in white sturgeon (Acipenser transmontanus). Aquaculture 507: 435-442. https://doi.org/10.1016/j.aquaculture.2019.03.009 
Flajšhans M (1997) A model approach to distinguish diploid and triploid fish by means of computer-assisted image analysis. Acta Veterinaria Brno 66(2): 101-110. https://doi.org/10.2754/ avb199766020101

Flajšhans M, Piačková V, Ráb P (2005) Higher ploidy levels in fish and some problems of their analysis. Analytická cytometrie III 3: 50-51.

Gervai J, Marian T, Krasznai Z, Nagy A, Csanyi V (1980) Occurrence of aneuploidy in radiation gynogenesis of carp, Cyprinus carpio L. Journal of Fish Biology 16(4): 415-439. https://doi. org/10.1111/j.1095-8649.1980.tb03721.x

Gregory TR (2001) Coincidence, coevolution, or causation? DNA content, cell size, and the C-value enigma. Biological Reviews of the Cambridge Philosophical Society 76(1): 65-101. https://doi. org/10.1017/S1464793100005595

Gregory TR, Mable BK (2005) Polyploidy in animals. Pp. 427-517 In: Gregory TR (Ed.) The evolution of the genome. Elsevier, San Diego, CA, USA. https://doi.org/10.1016/B978-012301463-4/50010-3

Hardie DC, Gregory TR, Hebert PDN (2002) From pixels to picograms: A beginners' guide to genome quantification by Feulgen Image Analysis Densitometry. Journal of Histochemistry and Cytochemistry 50(6): 735-749. https://doi.org/10.1177/002215540205000601

Kalous L, Knytl M, Krajáková L (2010) Usage of non-destructive method of chromosome preparation applied on silver Prussian carp (Carassius gibelio). Pp. 57-60. In: Kubík S, Barták M (Eds) Proceedings of the Workshop on Animal Biodiversity, July 7, Jevany, Czech Republic, 57-60. https://doi.org/10.25225/fozo.v60.i2.a5.2011

Kligermann AD, Bloom SE (1977) Rapid chromosome preparations from solid tissues of fishes. Journal of the Fisheries Research Board of Canada 34(2): 266-269. https://doi.org/10.1139/f77-039

Kotusz J (2008) Morphological relationships between polyploid hybrid spined loaches of the genus Cobitis (Teleostei: Cobitidae) and their parental species. Annales Zoologici 58(4): 891-905. https://doi. org/10.3161/000345408X396800

Kotusz J, Popiołek M, Drozd P, De Gelas K, Šlechtová V, Janko K (2014) Coexistence of C.taenia sexual and asexual forms. Biological Journal of the Linnean Society. Linnean Society of London 113 220-235. https://doi.org/10.1111/bij.12329

Leggatt RA, Iwama GK (2003) Occurrence of polyploidy in the fishes. Journal of Fish Biology 13(3): 237-246. https://doi.org/10.1023/ B:RFBF.0000033049.00668.fe

Lilyestrom CG, Wolters WR, Bury D, Rezk M, Dunham R (1999) Growth, carcass traits, and oxygen tolerance of ddiploid and triploid catfish hybrids. North American Journal of Aquaculture 61(4): 293-303. https://doi.org/10.1577/1548-8454(1999)061\%3C0293:GCTAOT\%3 E2.0.CO;2
Mason AS, Batley J (2015) Creating new interspecific hybrid and polyploid crops. Trends in Biotechnology 33(8): 436-441. https://doi. org/10.1016/j.tibtech.2015.06.004

Otto SP (2007) The evolutionary consequences of polyploidy. Cell 131(3): 452-462. https://doi.org/10.1016/j.cell.2007.10.022

Otto SP, Whitton J (2000) Polyploid incidence and evolution. Annual Review of Genetics 34(1): 401-437. https://doi.org/10.1146/annurev.genet.34.1.401

Pakosta T, Vetešník L, Šimková A (2018) A long temporal study of parasitism in asexual-sexual populations of Carassius gibelio: Does the parasite infection support coevolutionary Red Queen dynamics? BioMed Research International 2018: e6983740. https://doi. org/10.1155/2018/6983740

Papoušek I, Lusková V, Koščo J, Lusk S, Halačka K, Povž M, Šumer S (2008) Genetic diversity of Cobitis spp. (Cypriniformes: Cobitidae) from different drainage areas. Folia Zoologica 57: 83-89.

Piferrer F, Beamont A, Falguiére JC, Flajšhans M, Haffray P, Colombo L (2009) Polyploid fish and shellfish: Production, biology and application to aquaculture for performance improvement and genetic containment. Aquaculture 293(3-4): 125-156. https://doi.org/10.1016/j. aquaculture.2009.04.036

Preston AC, Taylor JF, Craig B, Bozzolla P, Penman DJ, Higaud H (2013) Optimisation of triploidy induction in brown trout (Salmo trutta L.). Aquaculture 414-415: 160-166. https://doi.org/10.1016/j. aquaculture.2013.07.034

Sadler J, Pankhurst PM, King HR (2001) High prevalence of skeletal deformity and reduced gill surface area in triploid Atlantic salmon Salmo salar L. Aquaculture 198(3-4): 369-386. https://doi. org/10.1016/S0044-8486(01)00508-7

Svoboda M, Kolářová J (1999) Přehled anestetik použivaných v chovech ryb [A survey of anaesthetics used in the fish farming.]. Pp. 49-72. In: Health protection of Fish - Proceedings of Conference Papers. VÚRH Vodňany, Czech Republic. [In Czech]

Thorgaard GH, Gall GAE (1979) Adult triploids in a rainbow trout family. Genetics 93(4): 961-973. https://doi.org/10.1093/genetics/93.4.961

Thorgaard GH, Rabinovitch PS, Shen MW, Gall GAE, Propp J, Utter FM (1982) Triploid rainbow trout identified by flow cytometry. Aquaculture 29(3-4): 305-309. https://doi.org/10.1016/0044-8486(82)90144-2

Vetešník L, Halačka K, Lusková V, Lusk S (2006) Erythrocyte profile of diploid and triploid silver crucian carp (Carassius aratus). Acta Veterinaria Brno 75(2): 203-207. https://doi.org/10.2754/avb200675020203

Wolters WR, Chrisman CL, Libey GS (1982) Erythrocyte nuclear measurements of diploid and triploid channel catfish, Ictalurus punctatus (Rafinesque). Journal of Fish Biology 20(3): 253-258. https:// doi.org/10.1111/j.1095-8649.1982.tb04706.x 